\title{
Self-defense in Karabakh Conflict?
}

\author{
Article
}

Published Version

Creative Commons: Attribution-Noncommercial-No Derivative Works 4.0

Open Access

Bagheri, S. ORCID: https://orcid.org/0000-0002-9398-8067 (2015) Self-defense in Karabakh Conflict? Russian Law Journal, 3 (4). pp. 150-164. ISSN 2309-8678 doi: https://doi.org/10.17589/2309-8678-2015-3-4-150-164 Available at https://centaur.reading.ac.uk/101844/

It is advisable to refer to the publisher's version if you intend to cite from the work. See Guidance on citing.

Identification Number/DOI: https://doi.org/10.17589/2309-8678-2015-3-4-150-164 $<$ https://doi.org/10.17589/2309-8678-2015-3-4-150-164>

Publisher: Supporting Academic Initiatives Foundation

All outputs in CentAUR are protected by Intellectual Property Rights law, including copyright law. Copyright and IPR is retained by the creators or other copyright holders. Terms and conditions for use of this material are defined in the End User Agreement.

\section{www.reading.ac.uk/centaur}

\section{CentAUR}

Central Archive at the University of Reading

Reading's research outputs online 


\title{
SELF-DEFENSE IN KARABAKH CONFLICT?
}

\author{
SAEED BAGHERI \\ Akdeniz University \\ (Antalya, Turkey)
}

DOI:10.17589/2309-8678-2015-3-4-150-164

Use of force is one of the principles of international law that has been banned by the UN Charter and modern constitutions. However, since the enforcement of the UN Charter, self-defense has become the preferred excuse for states to justify their use of force. Applying self-defense, however, requires some conditions. Immediacy is one of the important conditions of self-defense. This is defined as the timeframe between armed attacks and reaction to it. This situation requires self-defense immediately after the armed conflict or during a reasonable timeframe since its occurance.

In this respect, emerging Karabakh Conflict between Armenia and Azerbaijan in the $1990^{5}$ is important. In this article, by comparing two different approaches (strict and board interpretation) of the temporal link between the measures of self-defense and the armed attacks (immediacy), the temporal link between the self-defense countermeasures of Azerbaijan and attacks by Armenia in Karabakh Conflict will be examined.

Keywords: international law; armed attack; self-defense; immediacy; Karabakh Conflict.

Recommended citation: Saeed Bagheri, Self-Defense in Karabakh Conflict?, 3(4) RLJ (2015).

\section{Introduction}

In international law the right to self-defense is one of the most important exceptions to states' use of force. Moreover, prohibition of the use of force ${ }^{1}$ and

\footnotetext{
Funda Keskin, Uluslararası Hukukta Kuvvet Kullanma: Savaş, Karışma ve Birleşmiş Milletler 43
} (Mülkiyeliler Birliği Vakfı 1998). 
self-defense are one of the norms in regulating international relations which have been approved in UN Charter. UN Charter Art. 2(4) is the basic regulator of the use of force in international law. This article has clearly prohibited the use of force and the threat of the use of force in international relations.

The right to self-defense, identified in UN Charter Art. 51 has been clarified as the only exception to this provision. According to Art. 51 the fundamental condition for exercising the right of self-defense is an 'armed attack.' In this context, the time span between armed attack and self-defense is the most disputed subject (immediacy). Some experts interpret immediacy in a broad way and some others evaluate it in a strict manner.

UN Charter Art. 51 prescribes self-defense as the only exception to the prohibition of the use of force. However, self-defense should comply with international law principles. Throughout the past century, the principles of international law concerning the use of force have improved significantly. In this regard, it can be claimed that the UN Charter has lead to the most radical evolutions. ${ }^{2}$ In 1937, the US initiated dialogue with other states regarding taking measurements subsumed as use of force and self-defense in the framework of international law principles. This dialogue has had a dominant role in the appearance of 'necessity' and 'proportionality' principles. ${ }^{3}$ Necessity and proportionality have been identified as two basic conditions of states' use of force against each other. ${ }^{4}$

Consequently, self-defense is not a limitless right. According to the 'Caroline Doctrine, ${ }^{\prime 5}$ an action in self-defense requires a necessity that is 'instant, overwhelming, leaving no choice of means, and no moment for deliberation. ${ }^{6}$ Prohibition of the use of force has simultaneously acquired the quality of customary international law. Thus it binds those states and subjects which have not signed the UN Charter too. This status has been set forth by the Nicaragua case.' Examples encompassing the prohibition of the use of force are rather interpreted in the context of general

2 Lori F. Damrosch et al., International Law: Cases and Materials 920 (4 ${ }^{\text {th }}$ ed., West Pub. Co. 2001).

3 Charles C. Hyde, 3 International Law Chiefly as Interpreted and Applied by the United States 239 ( $2^{\text {nd }}$ ed., Little, Brown \& Co. 1945).

4 Jules Lobel, The Use of Force to Respond to Terrorist Attacks: The Bombing of Sudan and Afghanistan, 24 Yale J. Int'I L. 537, 537-43 (1999); W. Michael Reismann, The Raid on Baghdad: Some Reflections on Its Lawfulness and Implications, 5(1) Eur. J. Int'I L. 125 (1994), available at <http://ejil.oxfordjournals. org/content/5/1/120.full.pdf+html> (accessed December 10, 2015) doi:10.1093/oxfordjournals.ejil. a035861; Oil Platforms (Islamic Republic of Iran v. U.S.), 2003 I.C.J. 161, 176 (November 6); Military and Paramilitary Activities (Nicar. v. U.S.), 1986 I.C.J. 14, ๆ 176 (June 27); Advisory Opinion, Legality of the Threat or Use of Nuclear Weapons, 1996 I.C.J. 226, ๆ 41 (July 8).

5 See Martin A. Rogoff \& Edward Collins, Jr. The Caroline Incident and the Development of International Law, 16 Brook. J. Int'I L. 493 (1990).

6 R.Y. Jennings, The Caroline and Mcleod Case, 32 Am. J. Int'I L. 82, 89 (1938).

7 Supra n. 4, at 100. 
principles of international law. In short, we may conclude, that under customary law it is accepted that a state may use force against the aggressor, under the right of selfdefense, if it respects the conditions of proportionality, necessity and immediacy as expressed in the Caroline Doctrine - a doctrine which leaves a respectable scope for the exercise of discretion by the entity wishing to defend itself. ${ }^{9}$

The fundemental point in Security Council's interpretation is that the armed attack should be pre-designed. In the event that the counteraction - instead of being adopted to stop or prevent the attack - occurs after the previous attack has ended, then it exceeds the aim of self-defense. As a result, if a state adopts counteraction at the moment of being attacked with the aim of defending itself, it can be claimed that the victim state has complied with the condition of immediacy in self-defense.

Considering the wide scope of criticism regarding immediacy condition after the armed attack, should the friendly seeking of resolutions to the problem between the parties fail, the right to self-defense would be reserved by the victim state. In this regard, two different approaches to the subject would be analyzed and embodied by the Falkland Islands War and the Karabagh Conflict.

Therefore, prohibition of the use of force will be primarily overviewed, approaches identifying whether necessity condition and the timeframe between the armed attack and self-defense should be limited will accordingly be analyzed.

\section{Immediacy as an Action of Self-Defense Taken in Response to an Actual Attack}

There have been attempts to concretize the necessity test by introducing a temporal link between attack and response, at times also referred to as an issue of 'immediacy.'10 In other words,

as a reaction against an armed attack, self-defense would normally be expected to begin quickly after the initial attack has been launched, and one way of providing for this is by establishing temporal link. If an attack is on-going, this temporal requirement is met. This in turn makes necessity dependent upon the interpretation of the armed attack requirement: this dependence is an

8 Report of the International Law Commission on the Work of Its Eighteenth Session, 4 May - 19 July, U.N. GAOR, $18^{\text {th }}$ Sess., Supp. No. 9, U.N. Doc. A/CN.4/191, reprinted in 2 Yearbook of the International Law Commission 169, 172, 247 (1966), at <http://legal.un.org/docs/?path=../ilc/documentation/english/ reports/a_cn4_191.pdf\&lang=EFSRC> (accessed Dec. 10, 2015).

9 Ady Niv, The International Court of Justice under the Scrutiny of Article 51, 2 Israel Defense Forces Law Review 173, 176 (2005-06).

10 Judith Gardam, Necessity, Proportionality and the Use of Force by States 149-153 (Cambridge University Press 2004). In English literature some authors have used the terms 'immediacy' and 'imminency' interchangeably (see Michael N. Schmitt, Preemptive Strategies in International Law, 24 Mich. J. Int'I L. 513 (2003)). 
important factor in recent debates concerning the 'accumulation of events doctrine' potentially extending the period of armed attacks."

Immediacy is immanent in the nature of on-the-spot reaction: the employment of counter-force must be temporally interwoven with the armed attack triggering it. According to the immediacy principle, there will not be'an undue time-lag between the armed attack and the invocation of self-defense."12

Recourse to counteraction after anunacceptable period following the armed attacked will cause a break in the link between the armed attack and counteraction. Consequently, these counteractions will not be self-defense, but it will be in the nature of 'reprisals. ${ }^{{ }^{3}}$ Therefore, these later attacks would not entitle the victim state to resort to armed force. In such cases, the victim state should bring the attack to the attention of the UN Security Council under Ch. VII of the UN Charter. This analysis is in line with Arts. 49-54 of the International Law Commission's Draft Articles on Responsibility of States for Internationally Wrongful Acts, adopted in 2001, ${ }^{14}$ in which the Commission strictly excluded from its concept of 'countermeasures' any such measures amounting to a threat or use of force. ${ }^{15}$

Nowadays in the context of the aforementioned reasons, passage of a'reasonable period' after the armed attack and recourse to right of self-defense, is seen as an acceptable status. Determination of identity and location of attacking state has not been provided in UN Charter. Practically, in order to determine the identity of the attacking state by the victim state and to perform counteraction, the delay resulting from the victim state's intelligence accumulation and military force preparation is reasonable.

Accordingly, recourse to right of the self-defense may be delayed for some acceptable reasons. After the armed attack against the victim state, in order for using force in exercising counteraction, it is not possible to determine the reasonable period representing the time span in a discrete framework. ${ }^{16}$ The mentioned period

11 Christian J. Tams, The Necessity and Proportionality of Anti-Terrorist Self-Defense, in Counter-Terrorism Strategies in a Fragmented International Legal Order: Meeting the Challenges 373, 384 (Larissa van den Herik \& Nico Schrijver, eds.) (Cambridge University Press 2013). doi:dx.doi.org/10.1017/ CBO9781139178907.018

12 Yoram Dinstein, War, Agression and Self-Defense 203, 221 ( ${ }^{\text {rd }}$ ed., Cambridge University Press 2001).

13 A reprisal is 'an action that a state undertakes to redress an injury suffered during time of peace' (see Anthony C. Arend \& Robert J. Beck, International Law and the Use of Force: Beyond the U.N. Charter Paradigm 17 (Routledge 1993)).

14 Draft Articles on Responsibility of States for Internationally Wrongful Acts, in Report of the International Law Commission, U.N. GAOR, $53^{\text {rd }}$ Sess., Supp. No. 10, U.N. Doc. A/56/10 (2001), reprinted in 2 Y.B. Int'I L. Comm'n 20 (2001), U.N. Doc. A/CN.4/SER.A/2001/Add.1, at <http://legal.un.org/ilc/texts/instruments/ english/commentaries/9_6_2001.pdf> (accessed Dec. 10, 2015).

15 Id. Art. 50(1)(a), at 131.

16 Rein Müllerson \& David J. Scheffer, Legal Regulation of the Use of Force, in Beyond Confrontation International Law for the Post-Cold War Era 93, 104 (Lori Fisler et al., eds.) (Westview Press; ASIL 1995). 
would differ according to the concrete case. Falkland Islands War is a concrete example of this situation.

\section{Temporal Link between the Measures of Self-Defense and the Armed Attack: Comparing Two Different Approaches}

\subsection{Extensive Interpretation Approach}

According to this approach, moving forward to a war of self-defense is a timeconsuming process, especially in a democracy where the wheels of government grind slowly. ${ }^{17}$ Instead of promptly employing counterforce, the victim state elects to give amicable negotiations a try. If the negotiations fail, the action ought to be regarded as self-defense notwithstanding the lapse of time. ${ }^{18}$ In other words, after the negotiations - directly or indirectly - between the aggressor and victim state, if positive results are not achieved it does not get positive results, the victim state may use its right of self-defense.

Moreover, in the cases of war as an act of self-defense, detection of response to an armed attack by legislative, executive and military assault echelon of command certainly will take time. Meanwhile, armed attacks of the aggressive state could have ended. Accordingly, delay in the self-defense measures in this context will be justifiable, because a state under attack cannot be expected to shift from peace to war instantaneously. ${ }^{19}$

According to Yoram Dinstein, lapse of time is almost unavoidable when - in a desire to fulfill letter and spirit the condition of necessity - a tedious process of information gathering or diplomatic negotiations evolves. The first phase of the Gulf War is a prime example. ${ }^{20}$

Also, a justifiable delay in the response of the victim state may also occur when a region forcibly occupied by the aggressor is distant from the center of government, and lengthy preparations are required before the military machinery can function smoothly. The Falkland Islands War of 1982 concretizes this state of affairs. ${ }^{21}$ During the Falklands War, due to geographical distance, the United Kingdom did not start defensive action until several weeks after the occupation of the islands by Argentina. ${ }^{22}$

\footnotetext{
17 Dinstein, supra n. 12 , at 243.

18 Julio Barboza, Necessity (Revisited) in International Law, in Essays in International Law in Honour of Judge Manfred Lachs 27, 41 (Jerzy Makarczyk) (Martinus Nijhoff Pub. 1984).

19 Dinstein, supra n. 12 , at 242.

20 Id. at 210.

21 Id. at 243

22 For more information about the Falkland Islands War, see W. Michael Reisman, The Struggle for the Falklands, 93 Yale L.J. 287 (1983), available at <http://digitalcommons.law.yale.edu/cgi/viewcontent. cgi?article=1726\&context=fss_papers $>$ (accessed Dec. 10, 2015).
} 
History and common sense tell us that an aggressor, having seized the territory of people, might enjoy the fruits of his aggression while forestalling peaceful solutions through dilatory tactics or unreasonable conditions. In this instance, resulting countermeasures, despite the passage of a time interval, should be considered as legitimate self-defense. ${ }^{23}$

According to some authors, if the territory of a state is the object of military occupation ${ }^{24}$ resulting from the use of force in contravention of the provisions of the UN Charter, the victim state may choose to exercise the right of self-defense. ${ }^{25}$ Therefore, right of self-defense is a result of both the armed attack and occupation. If armed attacks persist despite ceasefire during the same conflict, the right of self-defense will continue for the victim state. In this regard, each stage of the conflict should not be evaluated separately from each other. Accordingly, proportionate actions of the victim state against the armed attacks and occupation should be considered as legitimate self-defense. Consequently, inherent right to self-defense covers all of the measures taken by victim state in response to armed attack and occupation. ${ }^{26}$

In short, the victim state must use the right of self-defense in a reasonable time. However, state practice suggests that a reasonably delayed response is acceptable where there is a need to gather evidence of the attacker's identity and / or collect the intelligence and military force in order to strike back in a targeted manner. ${ }^{27}$

\subsection{Narrow Interpretation Approach}

If the beginning of countermeasures are after the end of armed attack, this measures will certainly be beyond the scope of self-defense. However, states can always be in a position to respond immediately to the armed attack. Therefore, the victim state is to respond before the attack ends or while it is being carried out. In other words, if the victim state indicates that it will respond immediately and then exercises countermeasures without any break, the temporal link between armed attack and self-defense will be reasonable. Therefore, if the countermeasures take place after an unacceptable lapse of time, these measures cannot be considered

23 Oscar Schachter, The Right of States to Use Armed Force, 82 Mich. L. Rev. 1620, 1636 (1984).

24 Article 42 of the Hague Regulations of 1907 defines occupation as follows: 'Territory is considered occupied when it is actually placed under the authority of the hostile army. The occupation extends only to the territory where such authority has been established and can be exercised.'(see Contemporary Challenges to IHL - Occupation: Overview, ICRC (Jun. 11, 2012), <http://www.icrc.org/eng/war-and-law/ contemporary-challenges-for-ihl/occupation/overview-occupation.htm > (accessed Dec. 10, 2015).

Anthony Aust, Handbook of International Law 229 (Cambridge University Press 2005).

26 Jean Combacau, The Exception of Self-Defense in U.N. Practice, in The Current Legal Regulation of the Use of Force 9, 21 (Antonio Cassese, ed.) (Martinus Nijhoff Pub. 1986).

27 Angus Martyn, The Right of Self-Defense under International Law - the Response to the Terrorist Attacks of 11 September, 2001-02(8) Current Issues Brief, available at <http://www.aph.gov.au/binaries/library/ pubs/cib/2001-02/02cib08.pdf> (accessed Dec. 10, 2015). 
as self-defense. In short, if the countermeasures of the victim state in response to armed attack are taken at the moment of attacks, it is possible to say that the selfdefense measures are complying with the immediacy condition. However, according to immediacy condition, after the armed attack, use of force against the armed attack should not be delayed by the victim state. Nevertheless, the victim state may not have the opportunity to respond to the armed attack immediately.

If the victim state prolongs the interval between the armed attack and selfdefense, the countermeasures of victim state could turn into'retorsion ${ }^{28}$ as an action contrary to international law. Thus, the countermeasures of the victim state should be approved by the UN Security Council. Additionally, occupation of a state's territory gives rise to the right of self-defense, but the use of countermeasures against armed attack after unacceptable lapse of time will not be considered self-defense.

In short, as a reaction against an armed attack, self-defense would normally be expected to begin quickly after the initial attack has been launched, and one way of providing for this is by establishing a temporal link. Otherwise, countermeasures will be considered as 'reprisals.'29

\section{Karabakh Conflict}

\subsection{Historical Background}

The Nagorno Karabakh conflict can be considered a conflict based on state building. The fundamental issues on the status of the Nagorno Karabakh area are: internally displaced people, competing territorial claims, refugees and responsibility for atrocities during the armed phase of the conflict, have increased the confusion surrounding the situation, to name some. The conflict has long historical background and violence has accelerated at different times during its course. Between 1990-91 Armenia and the Soviet Union were involved in an armed battle over the territory. When the Soviet Union disintegrated, an armed conflict escalated between the Nagorno Karabakh and the government of Azerbaijan. On December 28, 1991, at the brink of the collapse of the Soviet Union, Nagorno Karabakh held elections to parliament after unilaterally proclaiming itself a republic..$^{30}$

The disintegration of the Soviet Union led to a power vacuum which consequently played a big role in the emergence of conflicts in $1990^{5}$. Karabakh was no exception

28 Self-defense is also very different from 'retorsion.' For more information, see Gerhard von Glahn \& James L. Taulbee, Law among Nations: An Introduction to Public International Law $637-640\left(7^{\text {th }}\right.$ ed., Allyn and Bacon 1996).

29 Reprisals are punitive in character: they seek to impose reparation for the harm done, or to compel a satisfactory settlement of the dispute created by the initial illegal act, or to compel the delinquent state to abide by the law in the future (see Derek Bowett, Reprisals Involving Recourse to Armed Force, 66 Am. J. Int'l L. 1, 3 (1972)).

30 Shahen Avakian, Nagorno Karabakh: Legal Aspects 22 ( $4^{\text {th }}$ ed., 'TIGRAN METS' Pub. House 2013). 
in this sense and soon after Soviet forces left the area it turned into a war zone. As a result, casualties rose to around $250 .^{31}$

Years of war starting from 1988 until 1994 were the result of Nagorno Karabakh's desire for self-determination and Azerbaijanis' strife for maintaining their territorial integrity. The conflict starting from 1988 between Azerbaijan and Armenia is the reason for more than twenty thousand casualties and around 1.5 million refugees, which in turn has led to a crisis for Azerbaijan in particular. Most of the major powers and international organizations consider Nagorno Karabakh conflict as an internal conflict. As a result, in optimistic terms the international community has behaved rather indifferently in solving the conflict; in pessimistic terms the international community has acted insufficiently to put an end to the conflict. There, obviously, is an intra-state aspect of Nagorno Karabakh conflict because the Armenian inhabitants of the area have fought for independence from Azerbaijan and have in this sense, been enforced by Armenia. In other terms, since early 1992 the conflict has gained an intrastate dimension as it has involved the two independent states of Armenia and Azerbaijan as conflict parties. In fact, the main problem in generating a solution to the Nagorno Karabakh conflict is the involvement of 'Republic of Nagorno Karabakh' besides Armenia and Azerbaijan. The mentioned issues have made this conflict one of the most contradictory issues in the international arena. Nagorno Karabakh conflict is the only ethnopolitical conflict in Caucasia that involves two independent states. The reflection of this virtue has emerged in alignments between states in Caucasia during the past three decades. Influenced by such alignments between states in the area, the regional security of Caucasia is greatly influenced by the Nagorno Karabakh conflict. ${ }^{32}$

Considering the threat that Nagorno Karabakh conflict poses to the area the international organizations have taken action. The main body leading the mediation efforts on this conflict is the Organization for Security and Cooperation in Europe [hereinafter OSCE]. ${ }^{33}$ The OSCE commenced its efforts in 1992 with the goal of arranging an international conference to settle the conflict. As the conference was to be held in Minsk (Belarus), it was called the 'Minsk Conference.'The preparation for the conference was realized with a group of concerned countries, including representatives of the Russian Federation, Sweden, Italy and other third parties as

31 Svante E. Cornell, Small Nations and Great Powers: A Study of Ethnopolitical Conflict in the Caucasus 81 (Curzon Press 2001), available at <https://is.muni.cz/el/1423/podzim2012/MVZ208/um/35586974/ Small_Nations_and_Great_Powers_A_Study_of_Ethnopolitical_Conflict_in_the_Caucasus_.pdf> (accessed Dec. 10, 2015).

32 For more information, see Cavid Abdullahzade, Hukuki Yönleriyle Dağlık Karabağ Sorunu (Adalet Yayınevi 2013).

33 See Bahar Başer, Third Party Mediation in Nagorno Karabakh: Part of the Cure or Part of the Disease?, 3(5) Journal of Central Asian \& Caucasian Studies (2008), available at <http://www.usak.org.tr/dosyalar/ dergi/lo3d6dJUUdzacB0o79Im6SLLxUPIKD.pdf> (accessed Dec. 10, 2015). 
well as representatives from Azerbaijan and Armenia. ${ }^{34}$ Although the Minsk Group has arranged numerous conferences on the subject of ending Nagorno Karabakh conflict, it has so far been unsuccessful in achieving a reconciliation of the conflict.

An important opportunity to intervention was lost at the very beginning, mainly due to internal dynamics (since both Azerbaijan and the self-proclaimed Nagorno Karabakh Republic at this point in time believed that the issue could be solved through armed conflict and none of the two sides were consolidated enough internally to make concessions) and partly because of external dynamics which could be considered in particular as lack of active, focused and united engagement from the international community, not least the Western powers. ${ }^{35}$

\subsection{Violation of the Prohibition of the Use of Force by Armenia}

Invasion or attacks by the armed forces of a foreign state, military occupation and bombardment - the highlights of Arts. 3(a)-(b) of the United Nations Definition of Aggression (UNGA Resolution 3314 (XXIX) of December 14, 1974) - constitute armed attacks, triggering the right of self-defense in accordance with UN Charter (Art. 51) and customary international law. ${ }^{36}$ Therefore, as for occupation:'When territory has been occupied illegally, the use of force to retake it will be a lawful exercise of the right of self-defense. ${ }^{137}$

The first armed attack by the Armenia against the Azerbaijan after the independence of the two Republics - an attack in which organized military formations and armored vehicles operated against Azerbaijani targets - occurred in February 1992, when the town of Khojaly in the Republic of Azerbaijan was notoriously overrun..$^{38}$ Armenian attacks against areas within the Republic of Azerbaijan were resumed in 1993, eliciting a series of four Security Council resolutions.

Essentially all of the states have the rights and obligations under international law, but individual domestic administrative bodies, such as union republics, are themselves not subject to international law. Accordingly, the prohibition of the use of force under international law applied to the Republic of Armenia after it acquired its national independence. On the other hand, for Azerbaijan, the precise point of

34 Jan Eliasson \& Mathias Mossberg, Nagorno-Karabach:Den Glömda Konflikten, 1998(2) Internationella Studier.

35 John J. Maresca, Resolving the Conflict over Nagorno Karabakh: Lost Opportunities for International Conflict Resolution, in Managing Global Chaos: Sources of and Responses to International Conflict 255 (Chester A. Crocker et al., eds.) (United States Institute of Peace Press 1996).

36 Kevin C. Kenny, Self-Defense, in 2 United Nations: Law, Policies and Practice 1162, 1164 (Rüdiger Wolfrum \& Christiane Philipp, eds.) (Martinus Nijhoff Pub. 1995).

37 Aust, supra n. 25, at 229.

38 Thomas de Waal, Black Garden: Armenia and Azerbaijan through Peace and War 170 (New York University Press 2003), available at <https://raufray.files.wordpress.com/2010/11/0814719449.pdf> (accessed Dec. 10, 2015). 
independence is debatable. However, with the dissolution of the USSR by the end of December 1991, there is no doubt that Armenia was independent. As a result, Armenia both enjoyed the rights of the international legal system and was subject to its obligations. Correspondingly, after the end of December 1991 the actions of the independent Republic of Armenia also had to be measured against the prohibition of the use of force under international law. ${ }^{39}$

Whether or not the accused administrative entity disaffiliates from the overall state over the further course of history, violations of provisions relating to the inner sovereignty of a state can scarcely have any consequences in international law. Fundamentally, obligations in international law are valid only for subjects of international law. Consequently, such an analysis under international law would concentrate rather on the conduct of the Republic of Armenia after the end of December 1991; that is, after the prohibition on the use of force under international law takes effect. ${ }^{40}$ In this regard, the UN Security Council reaffirms all its relevant resolutions, inter alia, on the principles of sovereignty and territorial integrity of all states in the region. It also reaffirms the inviolability of international borders and the inadmissibility of the use of force for the acquisition of territory.

The norm of territorial integrity applies essentially to protect the international boundaries of independent states. However, it also applies to protect the temporary, if agreed, boundaries of such states from the use of force. The Declaration on Principles of International Law Concerning Friendly Relations 1970 provides:

Every State likewise has the duty to refrain from the threat or use of force to violate international lines of demarcation, such as armistice lines, established by or pursuant to an international agreement to which it is a party or which it is otherwise bound to respect. Nothing in the foregoing shall be construed as prejudicing the positions of the parties concerned with regard to the status and effects of such lines under their special regimes or as affecting their temporary character. ${ }^{41}$

\subsection{Applicability of the Right to Self-Defense by Azerbaijan}

From a purely formal standpoint, this variant of actions of the sides, unfortunately, cannot be ruled out of the list of possible ones. That is, Azerbaijan may undertake a military action to liberate the areas of Azerbaijan occupied by Armenia and eliminate

39 Heiko Krüger, The Nagorno-Karabakh Conflict: A Legal Analysis 95 (Springer 2010).

40 Id.

41 Declaration on Principles of International Law Concerning Friendly Relations and Co-operation among States in Accordance with the Charter of the United Nations, G.A. Res. 2625, Annex, U.N. GAOR, $25^{\text {th }}$ Sess., Supp. No. 28, at 122, U.N. Doc. A/5217 (1970), at <http://www.un-documents.net/a25r2625. htm> (accessed Dec. 10, 2015). 
the insurgent enclave of Karabakh. ${ }^{42}$ Armenia, on the other hand, may seize new territories of Azerbaijan outside Karabakh, to force Azerbaijan to be more concessive. Formally, all parties to the conflict speak in favor of a peaceful settlement to the conflict, but recently, when the negotiations again came to a deadlock, Azerbaijan stressed that it did not rule out a military solution'for the restoration of the country's territorial integrity in accordance with the principles of the United Nations.'In Armenia's opinion, such behavior is not unexpected from the country which was defeated in the military operations. However, it is also evident that these kinds of statements by officials in Baku damage the search for compromise most, which above all, requires an atmosphere of mutual trust. In response, Azerbaijan asks the following question: would Armenia be ready to conduct peace talks with Azerbaijan if the latter had, with the aid of Russia, occupied territories of Armenia populated by Azeris and demanded of them the formation of a new independent Azeri state $?^{43}$

When an armed attack occurs through attacks by the armed forces of a foreign state, occupation and bombardment, the right of self-defense is solidified once and for all. This is important to keep in mind when successive rounds of fighting (punctuated by ceasefires) take place in the course of the same international armed conflict. It is wrong to appraise each round of combat as if it were a separate armed conflict (with a separate armed attack and a separate response by way of selfdefense). The commission of the original armed attack must be considered to be the defining moment. Any acts taken thereafter by the victim of the armed attack must be seen as falling within the general scope of the exercise of the same right of self-defense, in response to the same armed attack. 'The exception of self-defense, if accepted as valid, would legalize once and for all the initiatives taken to repulse the adversary by the state making it..44

In this respect, 'immediacy' has not been recognized by the International Court of Justice as a condition to the exercise of the right of self-defense. By contrast, some scholars believe that it is. All the same, immediacy does not present any real difficulty to the Republic of Azerbaijan in the present case, taking the view that, 'although immediacy serves as a core element of self-defense, it must be interpreted reasonably. ${ }^{\prime 5}$ More specifically, the main factors here are:

(i) time consumed by negotiations (designed to satisfy the condition of necessity) does not count;

42 Based on the administrative and territorial division of Azerbaijan, Armenian forces control the seven districts of Azerbaijan. These districts are as follows: Kelbajar, Lachin, Kubatli, Jebrail, Zangelan and Agdam, Fuzuli. The total land area is $7,634 \mathrm{~km}^{2}$.

43 Ali Abasov \& Haroutiun Khachatrian, The Karabakh Conflict. Variants of Settlement: Concepts and Reality 52 ( $3^{\text {rd }}$ ed., Areat; Noyan Tapan 2006).

44 For more information, see Combacau, supra n. 26, at 9, 21.

45 Terry D. Gill, The Temporal Dimension of Self-Defense: Anticipation, Pre-Emption, Prevention and Immediacy, 11(3) Journal of Conflict \& Security Law 361, 369 (2006). doi:10.1093/jcsl/krl018 
(ii) the Republic of Azerbaijan actually commenced to exercise its right of selfdefense as early as the summer of 1992 (shortly after the onset of the armed attack by the Republic of Armenia and without any undue time-lag). The fact that fighting was later suspended through acceptance of a ceasefire means that what is hangs in the balance today is not an initial invocation but a resumption of the exercise of the right of self-defense;

(iii) in any event, when an armed attack produces continuous effects (through occupation) - and in the time that lapsed since the start of the armed attack the victim does not sleep on its rights, but keeps pressing ahead with (barren) attempts to resolve the conflict amicably - the right of self-defense is kept intact, despite the long period intervening between the genesis of the use of (unlawful) force and the ultimate (lawful) stage of recourse to counter-force. The Republic of Azerbaijan as the victim of an armed attack - retains its right of self-defense, and can resume exercising it as soon as it becomes readily apparent that prolonging the negotiations is an exercise in futility.

Twenty two year-old ceasefire calls by the Security Council are scarcely relevant to the present circumstances. Ceasefires are no more than interludes. Indeed, it must not be forgotten that a prolonged ceasefire plays into the hands of an aggressor state that gained ground through its armed attack. 'In circumstances where the aggressor state has acquired control over territory pertaining prima facie to the defending state, a ceasefire would tend to entrench positions of control, and recovery through negotiations may prove a difficult, if not an impossible task. ${ }^{\prime 46} \mathrm{~A}$ ceasefire is merely supposed to be a springboard for diplomatic action - to provide'a breathing space for the negotiation of more lasting agreements. ${ }^{\prime 47}$ This is precisely what the Azeri side has been striving to accomplish all these years. But once Azerbaijan comes to the firm conclusion that a peaceful settlement - based on withdrawal by Armenia from Karabakh and surrounding areas - is unattainable, it is entitled to terminate the ceasefire and resume the exercise of self-defense.

\section{Conclusion}

For more than 22 years, the Republic of Azerbaijan has made efforts in good faith to resolve the dispute. There were direct negotiations conducted on various rungs of the political ladder between the Republic of Azerbaijan and the Republic of Armenia. Additionally, there has been mediation under the aegis of the OSCE the Minsk Process. Regrettably, the many years of expanded energy (not least, since 1994,

46 Kaiyan H. Kaikobad, Jus ad Bellum: Legal Implications of the Iran-Iraq War, in The Gulf War of 1980-88: The Iran-Iraq War in International Legal Perspective 51, 64-65 (Ige F. Dekker \& Harry H.G. Post, eds.) (Martinus Nijhoff Pub. 1992).

47 Sydney D. Bailey, Cease-Fires, Truces, and Armistices in the Practice of the UN Security Council, 71 Am. J. Int'I L. 461, 469 (1977). 
by the Co-Chairmen of the Minsk Group) have not produced any tangible results. Certainly, after more than 22 and a half years of fruitless negotiations and mediation the Republic of Azerbaijan is entitled to draw a line in the sand: the condition of necessity has certainly been satisfied, indeed exhausted. But, in cases of failure of diplomatic negotiations, the victim state may excercise the right of self-defense.

\section{References}

Abasov, Ali, \& Khachatrian, Haroutiun. The Karabakh Conflict. Variants of Settlement: Concepts and Reality 52 ( $3^{\text {rd }}$ ed., Areat; Noyan Tapan 2006).

Abdullahzade, Cavid. Hukuki Yönleriyle Dağlık Karabağ Sorunu (Adalet Yayınevi 2013).

Arend, Anthony C., \& Beck, Robert J. International Law and the Use of Force: Beyond the U.N. Charter Paradigm 17 (Routledge 1993).

Aust, Anthony. Handbook of International Law 229 (Cambridge University Press 2005).

Avakian, Shahen. Nagorno Karabakh: Legal Aspects $22\left(4^{\text {th }}\right.$ ed., 'TIGRAN METS' Pub. House 2013).

Bailey, Sydney D. Cease-Fires, Truces, and Armistices in the Practice of the UN Security Council, 71 Am. J. Int'I L. 461, 469 (1977).

Barboza, Julio. Necessity (Revisited) in International Law, in Essays in International Law in Honour of Judge Manfred Lachs 27, 41 (Jerzy Makarczyk) (Martinus Nijhoff Pub. 1984).

Başer, Bahar. Third Party Mediation in Nagorno Karabakh: Part of the Cure or Part of the Disease?, 3(5) Journal of Central Asian \& Caucasian Studies (2008), available at <http://www.usak.org.tr/dosyalar/dergi/lo3d6dJUUdzacB0o79Im6SLLXUPIKD.pdf> (accessed Dec. 10, 2015).

Bowett, Derek. Reprisals Involving Recourse to Armed Force, 66 Am. J. Int'I L. 1, 3 (1972).

Combacau, Jean. The Exception of Self-Defense in U.N. Practice, in The Current Legal Regulation of the Use of Force 9, 21 (Antonio Cassese, ed.) (Martinus Nijhoff Pub. 1986).

Cornell, Svante E. Small Nations and Great Powers: A Study of Ethnopolitical Conflict in the Caucasus 81 (Curzon Press 2001), available at <https://is.muni. cz/el/1423/podzim2012/MVZ208/um/35586974/Small_Nations_and_Great_ Powers_A_Study_of_Ethnopolitical_Conflict_in_the_Caucasus_.pdf $>$ (accessed Dec. 10, 2015).

Damrosch, Lori F., et al. International Law: Cases and Materials 920 ( $4^{\text {th }}$ ed., West Pub. Co. 2001).

Dinstein, Yoram. War, Agression and Self-Defense 203, 210, 221, 242-43 ( ${ }^{\text {rd }}$ ed., Cambridge University Press 2001). 
Eliasson, Jan, \& Mossberg, Mathias. Nagorno-Karabach: Den Glömda Konflikten, 1998(2) Internationella Studier.

Gardam, Judith. Necessity, Proportionality and the Use of Force by States 149153 (Cambridge University Press 2004).

Gill, Terry D. The Temporal Dimension of Self-Defense: Anticipation, Pre-Emption, Prevention and Immediacy, 11(3) Journal of Conflict \& Security Law 361, 369 (2006). doi:10.1093/jcsl/krl018

Glahn, Gerhard von, \& Taulbee, James L. Law among Nations: An Introduction to Public International Law 637-640 ( $7^{\text {th }}$ ed., Allyn and Bacon 1996).

Hyde, Charles C. 3 International Law Chiefly as Interpreted and Applied by the United States 239 ( $2^{\text {nd }}$ ed., Little, Brown \& Co. 1945).

Jennings, R.Y. The Caroline and Mcleod Case, 32 Am. J. Int'I L. 82, 89 (1938).

Kaikobad, Kaiyan H. Jus ad Bellum: Legal Implications of the Iran-Iraq War, in The Gulf War of 1980-88: The Iran-Iraq War in International Legal Perspective 51, 64-65 (Ige F. Dekker \& Harry H.G. Post, eds.) (Martinus Nijhoff Pub. 1992).

Kenny, Kevin C. Self-Defense, in 2 United Nations: Law, Policies and Practice 1162, 1164 (Rüdiger Wolfrum \& Christiane Philipp, eds.) (Martinus Nijhoff Pub. 1995).

Keskin, Funda. Uluslararası Hukukta Kuvvet Kullanma: Savaş, Karışma ve Birleşmiş Milletler 43 (Mülkiyeliler Birliği Vakfı 1998).

Krüger, Heiko. The Nagorno-Karabakh Conflict: A Legal Analysis 95 (Springer 2010).

Lobel, Jules. The Use of Force to Respond to Terrorist Attacks: The Bombing of Sudan and Afghanistan, 24 Yale J. Int'I L. 537, 537-43 (1999).

Maresca, John J. Resolving the Conflict over Nagorno Karabakh: Lost Opportunities for International Conflict Resolution, in Managing Global Chaos: Sources of and Responses to International Conflict 255 (Chester A. Crocker et al., eds.) (United States Institute of Peace Press 1996).

Martyn, Angus. The Right of Self-Defense under International Law - the Response to the Terrorist Attacks of 11 September, 2001-02(8) Current Issues Brief, available at <http://www.aph.gov.au/binaries/library/pubs/cib/2001-02/02cib08.pdf> (accessed Dec. 10, 2015).

Müllerson, Rein, \& Scheffer, David J. Legal Regulation of the Use of Force, in Beyond Confrontation International Law for the Post-Cold War Era 93, 104 (Lori Fisler et al., eds.) (Westview Press; ASIL 1995).

Niv, Ady. The International Court of Justice under the Scrutiny of Article 51, 2 Israel Defense Forces Law Review 173, 176 (2005-06).

Reisman, W. Michael. The Struggle for the Falklands, 93 Yale L.J. 287 (1983), available at $<$ http://digitalcommons.law.yale.edu/cgi/viewcontent.cgi?article=1726\&context=fss_ papers> (accessed Dec. 10, 2015).

Reismann, W. Michael. The Raid on Baghdad: Some Reflections on Its Lawfulness and Implications, 5(1) Eur. J. Int'I L. 125 (1994), available at < http://ejil.oxfordjournals. 
org/content/5/1/120.full.pdf+html> (accessed December 10, 2015). doi:10.1093/ oxfordjournals.ejil.a035861

Rogoff, Martin A., \& Collins, Edward, Jr. The Caroline Incident and the Development of International Law, 16 Brook. J. Int'I L. 493 (1990).

Schachter, Oscar. The Right of States to Use Armed Force, 82 Mich. L. Rev. 1620, 1636 (1984).

Schmitt, Michael N. Preemptive Strategies in International Law, 24 Mich. J. Int'I L. 513 (2003).

Tams, Christian J. The Necessity and Proportionality of Anti-Terrorist Self-Defense, in Counter-Terrorism Strategies in a Fragmented International Legal Order: Meeting the Challenges 373, 384 (Larissa van den Herik \& Nico Schrijver, eds.) (Cambridge University Press 2013). doi:dx.doi.org/10.1017/CBO9781139178907.018

Waal, Thomas de. Black Garden: Armenia and Azerbaijan through Peace and War 170 (New York University Press 2003), available at <https://raufray.files.wordpress. com/2010/11/0814719449.pdf> (accessed Dec. 10, 2015).

\section{Information about the author}

Saeed Bagheri (Antalya, Turkey) - LL.B., Ph.D., Assistant Professor at Department of International Law, Akdeniz University (Dumlupinar blvd., Campus, Antalya, 07058, Turkey; email: sbagheri@akdeniz.edu.tr). 